\title{
Pengembangan Budidaya Kopi Robusta Organik pada Kelompok Tani Sido Makmur Desa Pesangkalan Kabupaten Banjarnegara
}

\author{
Ahadiyat Yugi Rahayu ${ }^{1}$, Okti Herliana ${ }^{1}$, Ervina Mela Dewi ${ }^{2}$, Rostaman $^{3}$ \\ ${ }^{1}$ Laboratorium Agroekologi, ${ }^{2}$ Laboratorium Ilmu dan Teknologi Pangan, ${ }^{3}$ Laboratorium Perlindungan \\ Tanaman Fakultas Pertanian.Universitas Jenderal Soedirman. \\ Jl. Dr Soeparno No.61 Karangwangkal Purwokerto \\ Email korespondensi: o.herliana@gmail.com \\ DOI: https://doi.org/10.21107/pangabdhi.v5i2.6112
}

Artikel Diterima : 19 Agustus 2019/ Revisi : 11 September 2019/Terbit : 19 Oktober 2019

\begin{abstract}
Abstrak
Desa Pesangkalan Kecamatan Pagedongan termasuk daerah penghasil kopi robusta di Banjarnegara. Petani Kopi tergabung dalam kelompok tani Sido Makmur Produk kopi Pesangkalan Village mendapatkan sertifikat organik dari Lembaga Sertifikasi Pangan Organik (LSPO) Indonesian Organic Farming Certification (INOFICE). Masalah yang dihadapi adalah kualitas bibit yang belum baik, pengolahan bahan organik sebagai biofertilizer belum intensif, pengendalian hama penyakit tanaman secara terpadu belum maksimal dan proses pasca panen yang masih dikerjakan secara manual sehingga produksi kopi belum mampu memenuhi permintaan pasar. Tujuan kegiatan ini adalah: 1. Melakukan alih teknologi dan pendampingan kepada mitra mengenai pembuatan kompos organik dari kulit kopi 2. Melakukan alih teknologi dan pendampingan mengenai pengendalian hama penyakit terpadu pada tanaman kop menggunakan agensia hayati beuvaria sp dan trichoderma 3. Melakukan alih teknologi dan pendampingan mengenai teknik ppembuatan bibit kopi dari sumber stek dan benih. Metode yang digunakan untuk menyelesaikan persoalan mitra dalam kegiatan Program Pengembangan Produk Unggulan Daerah (PPUD) adalah sosialisasi, alih teknologi, pelatihan, praktek dan pembuatan demplot (percontohan) serta pendampingan dengan pendekatan Partisipatory Rural Appraisal (PRA), yaitu melibatkan partisipasi masyarakat secara aktif dalam setiap pelaksanaan kegiatan. Selanjutnya dilakukan pendampingan dan Evaluasi Hasil pendampingan ini mampu meningkatkan ketrampilan anggota kelompok tani Sido Makmur dalam penyediaan pupuk organik dan pengendalian Hama penyakit tanaman kopi secara ramah lingkungan menggunakan agensia hayati Beuvaria basiana dan trichoderma harzianum. Terdapat peningkatan kuantitas dan kualitas produksi kopi robusta organik.
\end{abstract}

Kata Kunci: Kopi robusta, pesangkalan, kelompok tani sidomakmur, PBKo

\section{PENDAHULUAN}

Komoditas kopi di Indonesia memegang peranan penting dalam sektor perekonomian, baik sebagai sumber pendapatan masyarakat, pemenuhan kebutuhan kopi domestik maupun sumber pendapatan devisa negara dari perdagangan ekspor. Saat ini Indonesia menempati urutan ke 4 produsen kopi dunia setelah Kolombia, Vietnam dan Brazil. Namun kurun waktu 3 tahun produksi mulai menurun. Penurunan produksi kopi disebabkan oleh pemupukan yang belum efisien dan keberadaan hama penyakit tanaman seperti hama penggerek buah kopi, hama penggerek batang, kutu kebul dan penyakit karat daun.

Beberapa daerah di Kabupaten Banjarnegara mempunyai kopi lokal yang kualitasnnya bagus, mempunyai cita rasa yang khas dan potensial untuk dikembangkan, sehingga diharapkan permasalahan produksi kopi yang menurun dapat ditingkatkan melalui peningkatan produksi di daerah-daerah sentra penghasil kopi. Pemerintah daerah Kabupaten Banjarnegara mendukung budidaya dan pengembangan produk kopi karena sudah sesuai dengan arah pembangunan jangka menengah Kabupaten Banjarnegara yang tertuang dalam dokumen Rencana Pembangunan Jangka Menengah Daerah (RPJMD) tahap ketiga yang menyatakan pengembangan agroindustri Banjarnegara maju berbasis pertanian.

Desa Pesangkalan Kecamatan Pagedongan dengan ketinggian tempat 400-800 meter di atas permukaan laut, merupakan salah satu daerah penghasil kopi robusta di Banjarnegara. Petani Kopi di desa Pesangkalan tergabung dalam kelompok tani Sido Makmur yang dibentuk sejak tahun 2007 yang diketuai oleh Sulistioro. Produksi kopi Kelompok tani Sido Makmur mempunyai merk dagang Kopi Pesangkalan Village. Anggota kelompok tani berjumlah 25 orang memliki luasan rata-rata 0,5-2 Ha dengan populasi tanaman berkisar antara 500-2000 
tanaman. Kopi robusta Pesangkalan memiliki keunggulan dibanding dengan kopi dari daerah lain karena menerapkan sistem pertanian organik. Tidak menggunakan zat kimia baik dari pestisida, pupuk maupun herbisida sebagai input dalam proses budidaya. Produk kopi Pesangkalan Village mendapatkan sertifikat organik dari Lembaga Sertifikasi Pangan Organik (LSPO) Indonesian Organic Farming Certification (INOFICE) di Bogor pada tahun 2017.

Kopi Robusta Pesangkalan dijual dalam bentuk green bean (biji kopi kering), roasted bean (biji kopi sangrai) dan ground coffe (kopi bubuk). Rata-rata penjualan dalam sebulan yaitu 1 kwintal untuk green bean, $30 \mathrm{~kg}$ untuk roasted bean dan $20 \mathrm{~kg}$ untuk ground bean. Konsumen kopi pesangkalan village adalah masyarakat seputar Banjarnegara. Bebrapa kedai kopi di Banjarnegara menjadi pelanggan tetap kopi produksi desa ini. Karakter kopi robusta memiliki citarasa aroma yang sangat tajam dengan rasa pahitnya. Jadi diperlukan kehati-hatian dalam mengolah proses pasca panen kopinya hingga menghasilkan kopi robusta yang memiliki karakter rasa cokelat dan manis terasa di lidah, dan tidak berasa getirnya.

Budidaya kopi robusta organik di Pesangkalan didasari pada Keprihatinan akan terjadinya degradasi tanah karena model penggunaan lahan yang intensif melebihi daya dukung ekologisnya serta penggunaan input kimiawi seperti pupuk pestisida dan herbisida (Eswaran et al., 1993), kondisi demikian termasuk pada usaha tani kopi (Lukner, 1996). Alasan lain adalah tuntutan dilaksanakannya sistem pertanian yang berkelanjutan (sustainable) dan ramah lingkungan (ecofriendly). Disamping itu konsumen kopi juga mulai beralih pada trend gaya hidup sehat yaitu memilih produk organik untuk dikonsumsi. Besarnya biaya pembelian pupuk karena terbatasnya akses pupuk subsidi menjadikan petani beralih pada pupuk organik. Petani memerlukan informasi sumber dan proses pembuatan pupuk organik. Hal ini perlu dicermati mengingat bahwa sejak 2009 untuk setiap tahunnya Indonesia telah mengkonsumsi 2,6 juta ton urea; 1,1 juta ton TSP; 0,2 juta ton $\mathrm{KCl}$ dan 0,4 juta ton ZA.

Hama penyakit tanaman pada budidaya kopi organik di Desa Pesangkalan yaitu penggerek batang, penggerek buah dan karat daun. Hama penggerek buah kopi (Hypothenemus hampei) atau PBKo merupakan hama utama yang sangat merugikan petani kopi di Indonesia. Hama ini dilaporkan menyerang seluruh pertanaman kopi
Arabika di Sulawesi Selatan. Persentase serangan dapat mencapai 30-60\% yang menyebabkan kehilangan hasil serta menurunnya mutu produksi (Sese et al., 2011). Tingkat kerusakan buah kopi robusta akibat serangan hama ini di Lampung berkisar 28-32\% (Swibawa dan Sudarsono, 2011). Salah satu alternatif pengendalian hama PBKo adalah pengendalian secara hayati.

Pengendalian secara hayati dapat dilakukan dengan penggunaan agensia pengendali hayati seperti jamur entomopatogen. Keberhasilan pemanfaatan jamur entomopatogen sebagai agen pengendali hayati hama di lapangan dipengaruhi oleh berbagai faktor. Paling tidak ada tiga faktor yang mempengarui keberhasilan tersebut di antaranya yaitu patogen, inang, dan lingkungan ( Robert dan Yendol, 1971 dalam Irianti et al., 2001).

Pengendalian hama penyakit yang belum intensif inilah yang menyebabkan produksi kopi belum optimal. Sejak beralih pada kegiatan budidaya kopi organik kelompok tani belum menemukan teknik pengendalian yang ramah lingkungan, sehingga baru sebatas memusnahkan lain adalah kualitas bibit yang belum baik, pengolahan bahan organik sebagai biofertilizer belum intensif. Untuk menjawab permasalahan yang dihadapi oleh Kelompok Tani Sidomakmur maka tim pengabdian masyarakat dari Fakultas Pertanian Universitas Jenderal Soedirman tergerak memberikan pendampingan bagaimana memberikan input-input organik dalam kegiatan budidaya kopi robusta di desa pesangkalan. Tujuan kegiatan ini adalah: 1. Melakukan alih teknologi dan pendampingan kepada mitra mengenai pembuatan kompos organik dari kulit kopi 2. Melakukan alih teknologi dan pendampingan mengenai pengendalian hama penyakit terpadu pada tanaman kop menggunakan agensia hayati beuvaria sp dan trichoderma 3 . Melakukan alih teknologi dan pendampingan mengenai teknik ppembuatan bibit kopi dari sumber stek dan benih.

\section{METODE}

Kegiatan Pengabdian Kepada Masyarakat ini dilaksanakan pada bulan Maret-Oktober 2019 dengan Mitra kegiatan kelompok tani Sidomakmur Desa Pesangkalan Kec Pagedongan, Banjarnegara. Bahan yang digunakan dalam kegiatan ini adalah bibit kop, isolate Beuvaria basiana, isolate Trichoderma harzianum, jagung pipil yang di cacah, agar, acetone, spirtus, hypotan, pupuk kandang ayam, EM4, Molase, kapur dolomite dan kulit kopi. Alat yang 
digunakan dalam kegiatan ini adalah: panci dandang, kompor, botol air mineral bekas, cutter, tali kasur, tissue air mineral, cat pilox.

Metode yang digunakan untuk menyelesaikan persoalan mitra dalam kegiatan Program Pengembangan Produk Unggulan Daerah (PPUD) adalah sosialisasi, alih teknologi, pelatihan, praktek dan pembuatan demplot (percontohan) serta pendampingan dengan pendekatan Partisipatory Rural Appraisal (PRA), yaitu melibatkan partisipasi masyarakat secara aktif dalam setiap pelaksanaan kegiatan. Selanjutnya dilakukan pendampingan dan Evaluasi.

Tahapan pelaksanaan kegiatan meliputi: Sosialisasi, Penyuluhan, Pelatihan dan Praktek dengan materi sebagai berikut:

a. Teknik budidaya kopi secara organik dengan aplikasi pupuk kompos kulit kopi

b. Teknik pengendalian hama penyakit tanaman kopi secara terpadu dengan biopestisida berbahan baku sumberdya lokal dan agensia hayati.

c. Teknik pembuatan bibit kopi secara vegetative dari stek yang bagus dan penyemaian benih kopi klon 288 dari Balitkoka

d. Teknik pemanenan kopi dan pasca panen yang efisien.

\section{HASIL DAN PEMBAHASAN}

Kegiatan pengabdian kepada masyarakat "Program Pengembangan Produk Unggulan Daerah" pendampingan terhadap kelompok tani "Sido Makmur' dalam menjalankan kegiatan usaha dan budidaya dan penjualan produk kopi organik mendapat sambutan yang positif dari seluruh anggota kelompok, perangkat desa dan pemerintah daerah kabupaten banjarnegara. Kegiatan diawali dengan sosialisasi dan koordinasi terkait program yang akan dijalankan supaya tim pengabdi mendapatkan masukan dan informasi secara langsung terkait permasalahan yang dihadapi mitra

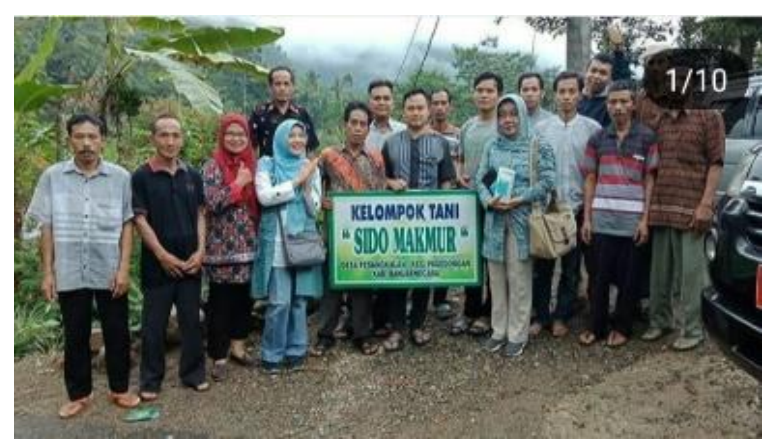

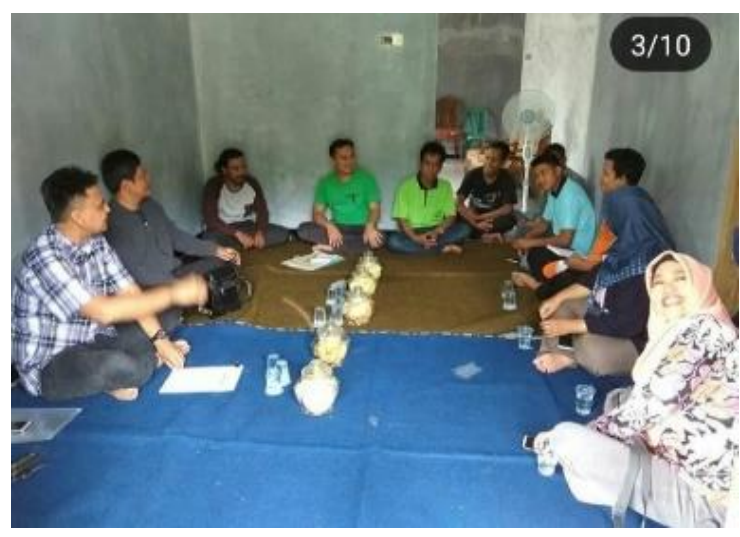

Gambar 1. Kegiatan koordinasi

Kegiatan dilanjukan dengan penyuluhan dan pelatihan pembuatan kompos organik. limbah kulit kopi yang belum dimanfaatkan petani secara optimal. Limbah padat buah kulit kopi ini memiliki kadar bahan organik dan unsur hara yang dapat memperbaiki struktur tanah. Salah satu upaya yang dapat dilakukan untuk penanganan jumlah limbah kulit kopi yang semakin meningkat yaitu dengan cara pengolah limbah kulit kopi menjadi kompos.

Menurut Muryanto et.al (2004), limbah kulit kopi yang diperoleh dari proses pengolahan kopi dari biji utuh menjadi kopi bubuk. Bahan: kulit buah kopi, $300 \mathrm{~kg}$ pupuk kandang, $20 \mathrm{~kg}$ Dolomit, Gula, Dekomposer (EM-4 1 liter/ton dan trichoderma $2 \mathrm{~kg} / \mathrm{ton}$ ), Air Sedangkan alat-alat yang dibutuhkan adalah: Timbangan, Ember, Cangkul, Garu, Terpal. Prosedur pembuatan kompos: Kulit buah kopi sisa pengolahan biji kopi disikan kedalam bak-bak tempat kompos, bersamaan waktu juga diisikan pupuk kandang, kemudian ditaburi dolomit, gula serta disiram dengan decomposer dan juga air. Semua bahan tersebut dibuat berlapis-lapis sampai tinggi tumpukan di dalam bak minimal $75 \mathrm{~cm}$. Setelah proses berlangsung, suhu dalam bak naik hingga kurang lebih $50^{\circ} \mathrm{C}$, tapi setelah itu suhu akan turun lagi. Setiap 2 minggu sekali bahan di bakbak tersebut dibalik dan jika ternyata terlalu kering maka dilakukan penyiraman. Setelah $2-3$ bulan kompos telah masak. Kompos siap dikemas atau langsung diapllikasikan

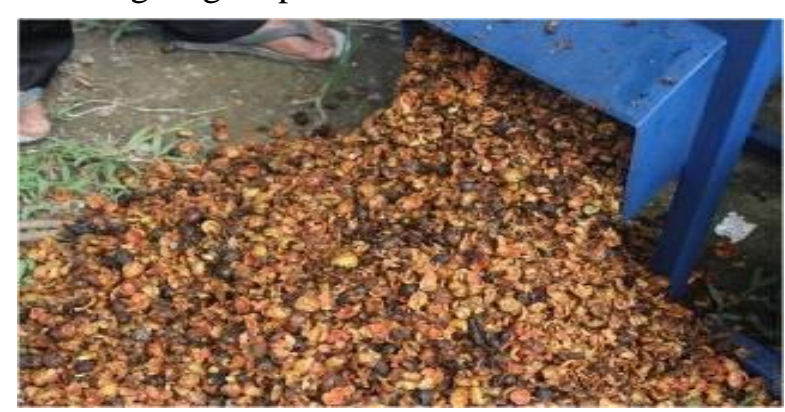




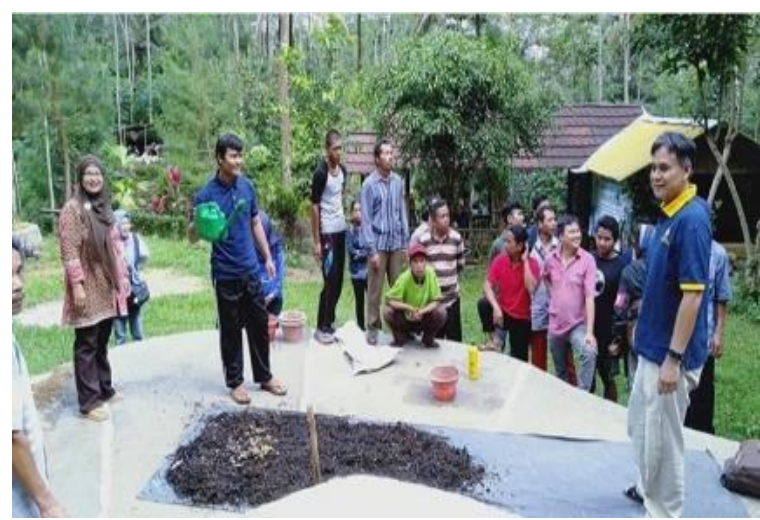

Gambar 2. Pelatihan dan Praktek Pembuatan Kompos Kulit Kopi

Kopi sangat rentan terhadap serangan hama dan penyakit. apalagi jika kurang dalam melakukan perawatan, menjaga sanitasi kebun dan melakukan pemangkasan akan menyebabkan tanaman kopi akan rusak yang tentunya mampu menurunkan produktifitas dari pada kopi tersebut. Masalah yang dihadapi oleh kelompok tani di desa pesangkalan adalah keberadaan OPT (Organisme Penggangu Tanaman). Karena produk kopi sudah mendapatkan sertifikasi organik maka pengendalian OPT yang dilakukan harus menggunakan bahan-bahan yang ramah lingkungan.

Pengendalian hama penyakit tanaman dengan memanfaatkan agensia hayati berbasis trichoderma dan beuvaria sp. menjadi satu alternatif pengendalian OPT tanaman kopi secara terpadu dan ramah lingkungan. Hama dan penyakit yang menyerang adalah PBKo (Penggerek Buah kopi) dan karat daun, untuk mengatasinya tim pengabdian memberikan alih teknologi berupa pelatihan dan praktek pembuatan perangkap feromon dengan bahan aktif hypotan, aceton dan metanol.Teknik pengendalian lain menggunakan Beauveria bassiana merupakan jamur/cendawan yang dapat digunakan sebagai agen pengendali hayati hama PBKo. Cara kerja cendawan ini akan membuat sakit serangga hama, baru kemudian menyebabkan hama tersebut mati. Jamur ini masuk kedalam tubuh serangga dapat melalui kulit, saluran pencernaan, maupun lubang lain yang ada pada serangga. Aplikasi jamur Beauveria bassiana dilakukan pada saat buah masih muda. Kebutuhan untuk 1 Ha kebun kopi yaitu $2,5 \mathrm{~kg}$ media biakan jamur B. bassiana selama 3x aplikasi per musim panen. Penyemprotan dilakukan pada sore hari dengan arah semprotan dari bawah daun selama $3 x$ aplikasi per musim panen. Penyemprotan dilakukan pada sore hari dengan arah semprotan dari bawah daun.
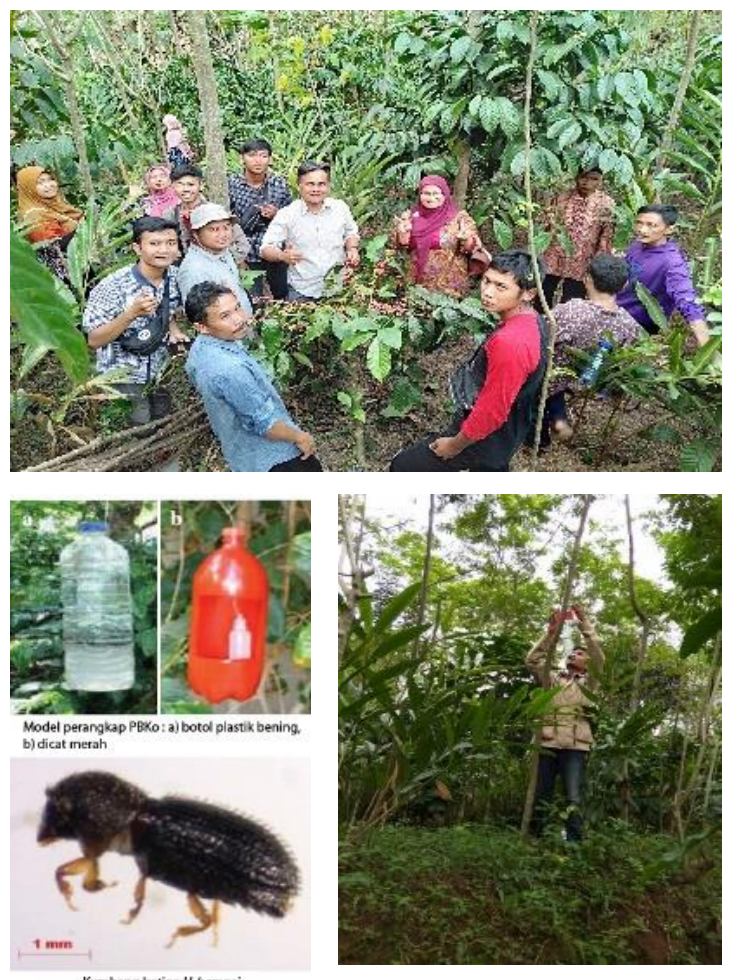

Gambar.3 Penyuluhan dan Praktek Pengendalian Hama PBKo
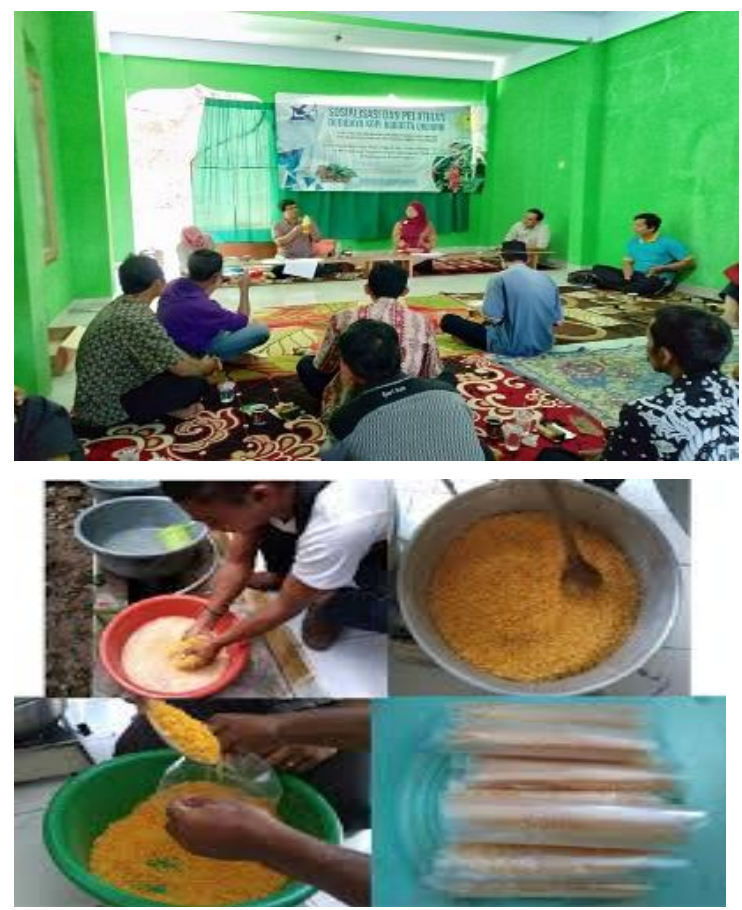

Gambar 4. Penyuluhan dan Perbanyakan Beauveria.

Guna mendukung kegiatan pengembangan budidaya kopi robusta organik, Tim pengabdi juga memberikan alat stek untuk tiap anggota agar dapat memilih dan menyiapkan bahan tanam berupa stek dan memberikan bahan tanam, berupa bibit kopi berumur 8 bulan sebanyak 5000 pohon 
dan benih kopi klon 288 dari balitkoka sejumlah 4000 butir benih. Dukungan dari pemerintahan desa berupa penggunaan lahan bengkok di area curug pletuk sebagai demplot budidaya kopi robusta seluas 6 ha. Selain ditujukan sebagai peningkatan kapasitas produksi kopi juga sebaga usaha konservasi lingkungan pada area lahan yang miring agar tidak mudah mengalami erosi.
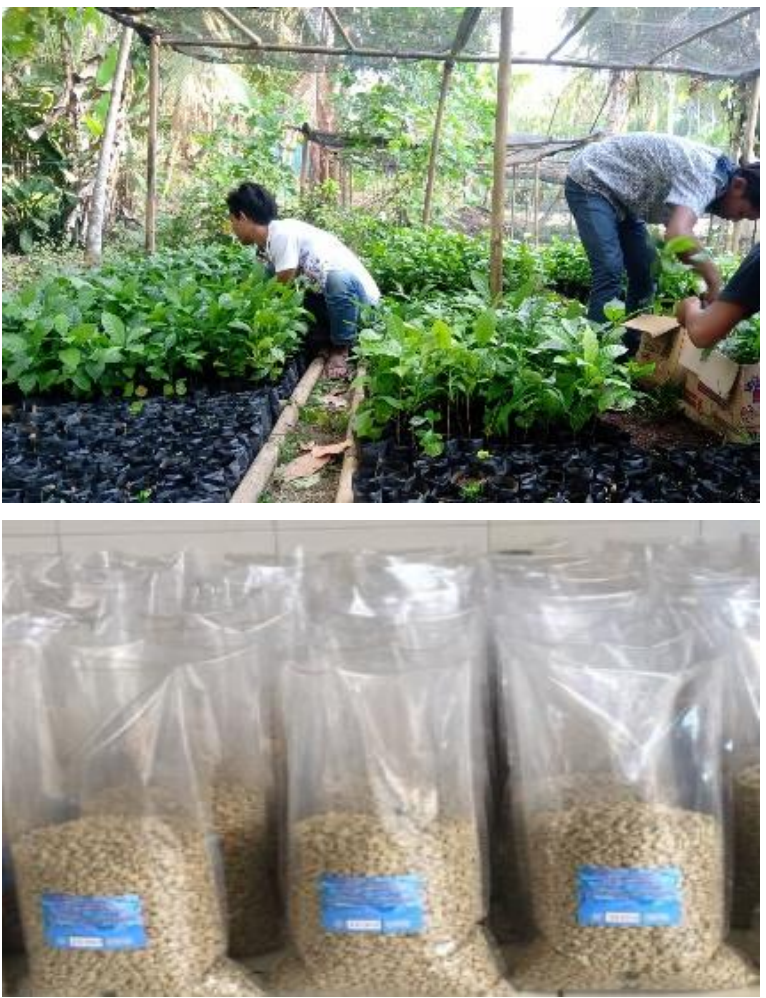

Gambar. 5 Proses Sortir Bibit dan Benih Kopi

Proses panen dan pasca panen yang dilakukan oleh kelompok Sidomakmur dilakukan secara manual, untuk meningkatkan kapasitas produksi maka tim pengabdi diberikan hibah alat untuk mempercepat proses produksi kopi. Saat masih menggunakan sistem manual, yaitu penyangrai manual yang harus diputar selama 20 menit agar kualitas kopi sangria yang dihasilkan merata, dalam proses grinding juga masih menggunakan alat semi manual dengan kapasitas kecil, sehingga memerlukan waktu lebih lama dalam penyediaan kopi kemas siap saji. Hibah berupa mesin roasting dan greender mekanis. Dengan kapasitas $40 \mathrm{~kg}$ dan greander kapasitas $10 \mathrm{~kg}$. Terdapat efisiensi waktu dan tenaga setelah alat yang dihibahkan digunakan untuk proses pasca panen kopi menjadi produk siap jual ke konsumen. Target luaran yang dicapai dalam kegiatan ini menunjukkan hasil yang cukup menuaskan, terjadi penambahan jumlah anggota kelopok tani yang membudidayakan kopi secara organik, terdapat perluasan lahan usaha budidaya kopi organik yang semula $25 \mathrm{Ha}$ menjadi 31 Ha. Terdapat penambahan alat produksi kopi bubuk secara mekanis dan terdapat peningkatan produksi kopi. Secara berkala kegiatan dilakukan monitoring dan evaluasi terhadap kegiatan pendampingan budidaya organik ini untuk menentukan arah keberlanjutan dan tingkat keberhasilan.
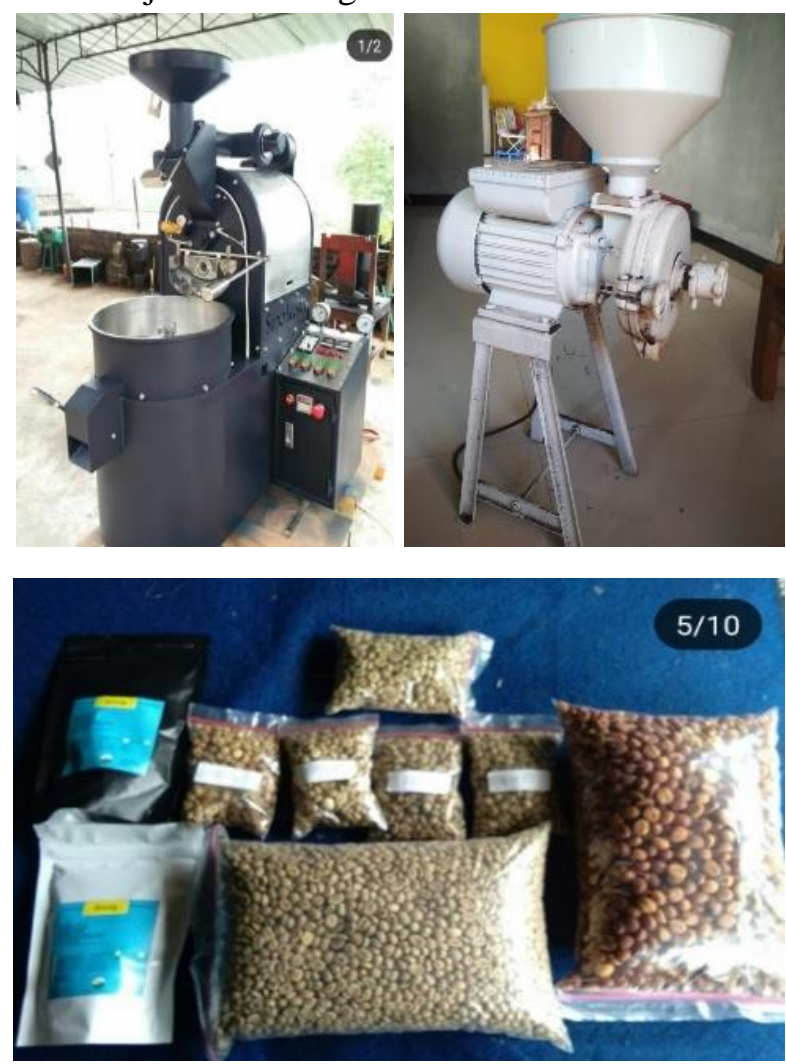

Gambar 6. Mesin Roasting, Greender Mekanis dan Produk Jual Kopi
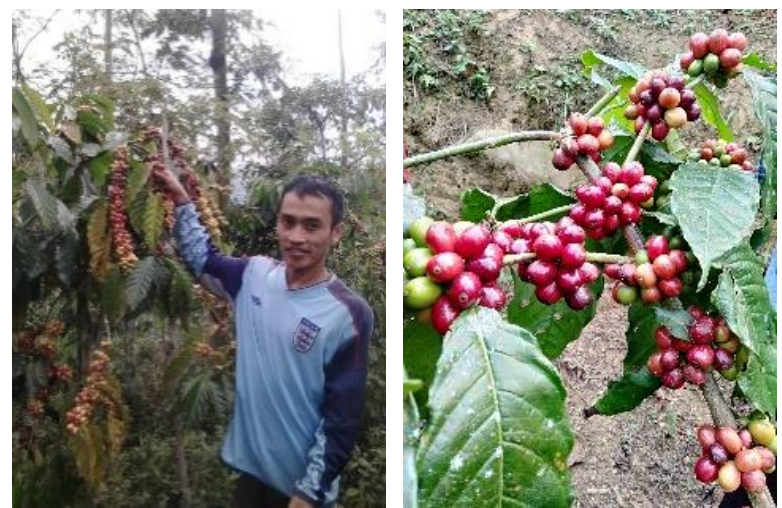

Gambar 7. Proses Panen Kopi

\section{KESIMPULAN}

Kegiatan pendampingan oleh tim pengabdi mampu meningkatkan ketrampilan anggota kelompok tani Sido Makmur dalam penyediaan pupuk organik dan pengendalian Hama penyakit tanaman kopi secara hayati menggunakan agensia 
hayati Beuvaria basiana dan trichoderma. Terdapat peningkatan kuantitas dan kualitas produksi kopi robusta organik di Desa Pesangkalan. Respon mitra dan perangkat desa cukup bagus.

\section{UCAPAN TERIMA KASIH}

Penulis mengucapkan terimkasaih kepada DRPM DIKTI atas hibah pendanaan Pengabdian Kepada Masyarakat skim Pengembangan Produk Unggulan Daerah (PPPUD) dengan No Kontrak: P/1988/UN23/14/PM/2019, LPPM Universitas Jenderal Soedirman, Mahasiswa yang membantu proses kegiatan (Dewi, Fahmi, Shofwan, Fajri, Agung dan Syifa) serta laboran (Ruswanto) sehingga kegiatan ini dapat berjalan dengan baik.

\section{DAFTAR PUSTAKA}

Baon, J.B, S. Wiryadiputra dan E. Sulistyowati. 1998. Pengaruh Infeksi Mikoriza Terhadap Serangan Nematoda Prtylenchus Coffee pada Tanaman Kopi. Pelita Perkebunan Vol 4 : 22-30 pp.

Bouma, J. 2002. Land Quality Indicators Of Sustainable Land Management Across Scales. Agriculture, Ecosystems and Enviroment. Vol 88. 129-136 pp.
Direktorat Jenderal Perkebunan. 2014. Statistik Perkebunan Indonesia (Kopi). Direktorat Jenderal Perkebunan.

Eswaran, H., S.M.Virmani \& L.D. Spivey Jr. 1993. Sustainable Agriculture In Developing Countries: Contraints, Chalanges and Choices.pp 7-24. In J. Ragland \& R. Lal- (Eds) Technologgies for Sustainable Agriculture in the Tropics. ASA Spec. Pub. No. 56. ASACSSA-SSSA.

Hartono. 2013. Produksi Kopi Nusantara Ketiga Terbesar di Dunia. Siaran Pers http://www.kemenperin.go.id/artikel/6611/ Produksi-Kopi-Nusantara-Ketiga-

Terbesar- Di-Dunia Diakses pada tanggal 24 Februari 2016.

Rubiyo, S. Guntoro dan Suprapto. 2003. Usaha Tani Kopi Robusta dengan Pemanfaatan Kotoran Kambing Sebagai Pupuk Organik di Bali. Jurnal Pengkajian dan Pengembangan Teknologi Pertanian. Vol. 6 (1). 73-80 pp.

Verma, L.N. 1993. Biofertilizer in agriculture. In Organics in Soil Health and Crop Pruduction (Ed. P. K. Thampan). Peekay Crops Dev. Found., India. 